\title{
Integrating The Thematic Instruction for The First Grade of Elementary Students by Using "The Mouse Deer and Snail" Big Book Literate Story
}

\author{
Ratna Trieka Agustina \\ Universitas Negeri Malang \\ harti.kartini.fip@um.ac.id
}

\author{
Harti Kartini \\ Universitas Negeri Malang
}

\begin{abstract}
Based on the Indonesian elementary school curriculum 2013, the focus of the instructional is based on thematic which should integrate many subjects. The aim of the research is to create the fable literature story big book. The title is "Mouse Deer and Snail". This book is created and developed based on (1) the content material, (2) the language, and (3) The illustration which appropriate for the metal development of the first grade elementary students. The result shows that the content area of the fable literature story book can make the teacher easy to integrate the thematic instructional naturally and meaningful for the first grade students of elementary school. The language makes the students easier to understand the story. The illustration which create colorful can make the students enjoy to study and can make the instructional concrete. It's hoped that the elementary teachers can develop or create the other media that can integrate the thematic instructional contextual, meaningful, and natural.
\end{abstract}

Keywords: integrate, thematic instructional, literate story book.

\section{INTRODUCTION}

The Indonesian Curriculum of the elementary education 2013 focus on main competences which are spiritual, social, knowledge and skill. Each of the subject is presented integrated, meaningful and natural instructional. Thematic here means all of the learning contents are under one theme. The aspect of moral and spiritual have great emphasized $(70 \%)$ rather than the knowledge aspect $(30 \%)$.

In order to effectively build the moral and attitudes of the learners, each learning activity will be based on aesthetical and behavioral value. Integration, context, authenticity, and purposiveness of learning activities can be presented through literature story book [1]. The language competences of the students, including reading, writing, listening, and speaking competence, can be developed by actively engaging the students with the storyline[2]. The students will not simply be able to enhance their language competences by learning the principles of the target language; instead, the students are required to directly use the target language. "Children increase their ability to use language by becoming involved with language"[3].

By engaging the students with storytelling activity, they can use their language competences through (1) recognizing alphabets, (2) shared reading, (3) writing their favorite parts of the story and (4) role playing in their preferable ways[4]. The teacher may try to explain the storyline in order to combine integrated themes with the curriculum and develop the moral value of the story in building students character. Later on, by using literature books in storytelling activity, the students may acquire aesthetic reading ability. "Aesthetic reading opens up worlds of possibilities for teaching with literature"[5].

According to the result of PPLG 2015 district 115 of elementary teachers in Batu City, it turns out that theme-based learning nowadays is mostly student activity book-oriented, which means that the teachers do not encourage any creative innovation in their teaching and learning activities. Aside from teacher guidebook and student activity book, the teachers are required to make use any other learning media creatively. Unfortunately, most schools still suffer from the lack of literature books which are well-composed in terms of content, language mechanics, and illustrations that are suitable for the mental age and language development of first grade students of elementary school. Therefore, the literature books used in theme-based learning for first grade students of elementary school should be well-developed with proper regard to the content appropriateness, language mechanics, and illustration.

Big Book is one of the story books that can be used in theme-based learning as it consists of storyline written in large font and large picture, colorful illustration, thus can be classically attractive to elementary students[6]. The objective of the literature books development is to describe literature book that can be used as learning material for first grade students of elementary school. The descriptions used to combine different subjects in theme-based learning for first grade students are including the content of the story, language mechanics, and illustration.

\section{METHOD}

This research was a development research, which will expand the literature story book. This development uses qualitative descriptive approach. The approach was used to describe things as follows (1) the description of the story content which is adapted for the development of first graders mental development, (2) the description of the language and (3) the description about illustration pictures.

Generally, the framework for this research is based on the framework for research and development which is proposed by Borg and Gall (1979), which is (1) need survey (2) planning, (3) early format development, (4) early trial with limited scale, (5) revision based on the result from the early trial, (6) field trial, (7) revision based on the result from the field, (8) field operational trial within bigger scale, (9) final revision based on the result of the field operational trial, (10) completion and distribution. In this development, not all of the steps are applied because there will be some modifications. 


\section{RESULT}

The "Mouse Deer and Snail" fable literature big story can be used in combining different subject matter on 7 Themes; the objects were Animal and Plants with Sub-theme 2: Animal in my surrounding consisting of learning activities 1-6. Those Lessons are: Indonesian language, Art and culture education (SBDP) and Civics Education. Lessons 2: Indonesian language and mathematic, Lessons 3: Civics Education, Physical Education and Indonesian language. Lessons 4: Art and Cultural Education (SBDP) and Indonesian language. Lessons 5: Indonesian language and Mathematic. Lessons 6: Mathematic, Indonesian language and Physical Educational.

The distribution draft of the learning media combined with literature fable story big book work entitle "The Mouse Deer and The Snail" were distinguished into different clusters learning activities (subject).Each one of the different subject matters combined with the story line of "The Mouse Deer and The Snail" literature story book. The result of this research show that the "Mouse Deer and Snail" story book can integrate many subject matters.

Elementary students were in concrete operational development stage. Its mean that student will easily understand if the learning was presented concretely. Piaget stated that cognitive development occurs during four stages, namely sensory motor, preoperational, concrete operational and formal operational. First grader of primary school child is still in the development of concrete operational level[7]. Piaget states that during the stages of cognitive development of children aged 7-11 years who are in elementary age levels, the child can think logically about concrete events and classify objects into existing forms[7].

In this case, the literature story of "Mouse Deer and Snail" explain and create language environment. Through the literature story: The Mouse Deer and Snail, students could develop their language skills, i.e., reading, listening, and speaking. Elementary age is an age when language is developed creatively. Robert E Quens states that the school age is a period of very creative language development[8]. The literature story is created in the choice of words which are easy to understand by the students and is concrete. The concrete word is a word that can be captured by the senses that enable the emergence of the imagination[9]. Exposed vocabularies which are repeated deliberately are intended to create a language environment that allows the students to recognize those vocabularies. Simple exposure of sentence follows simple sentence plot, so that the students are easy to understand the contained meaning. Simple sentence level was the subject, predicate and description.

The story book is created in great shape with illustrations based on the level of mental development of children of primary school age who enjoys colorful illustrations. The cover story is created with pictures representing the contents of the story (Figure 1). "The Mouse Deer and Snail" cover is packed with a picture of a beauty. The illustration is interpreted as everything functioned to explain, animate, and beautiful life stories, events, and so forth[10]. The illustrations are the types of images created to explain a story, moreover it functions to clarify the contents of the story and the illustration also provides traction or decoration display of the story book. The story illustrations could help capture children's attention to stories and facilitate their understanding and retention of what is being read to them[11].

The story of The Mouse Deer and Snail is simplified in accordance with the moral and language development of children's first grader and is packed as follows.

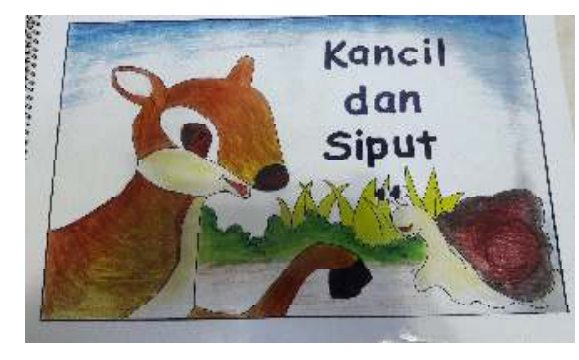

Figure 1. Cover of big book story prototype

The language simplification was tailored to the language development of children of primary school first grade. Thus, they will easily understand the story.

\section{CONCLUSION}

The literature content of The Mouse Deer and Snail full fills map elements of children's stories including elements of plot or storyline, clarity of characterization, concrete exposure story, which corresponds to the maturity level of the student's thinking, as well as sharpen social sensitivity, moral and feelings. By using Mouse Deer and Snail the teacher can easily integrate the thematic instructional that contains variety of subject matters at the first grades student of elementary school. The instructional can be presented contextual meaning full and natural. In addition, the story of "The Mouse Deer and Snail" also trains the children to communicate. Literature story titled "The Mouse Deer and Snail" enables the mindset of children in a way to predict or to explore the content of the story. The literature story contains the aesthetics content, enabling teachers to relate it to the core competences 1 which are associated with a spiritual aspect to be grateful for the grace of God and core competencies 2 in curriculum 2013 related to the social and moral associated with sincerity in helping others, not expecting rewards, and the willingness and humility to want to apologize.

Literary language is presented in accordance with the level of thinking of children with exposure to a language that is not too long (subject, predicate, and object). Presentation of the story titled "The Mouse Deer and Snail" is presented in accordance with the level of social and emotional development, accuracy of grammar and spelling, message understanding, terms standardization, and integrity that builds language exposure as a whole grain. Proper and correct exposure of language provides optimal language environment, and delight children of primary school age.

Attractive illustrations, colorful and appropriate level of elementary school age children development are in great demand and present a fun learning. Illustration cover image depicting the story optimize the imagination of the students and motivate students to think critically and creatively.

Primary school teachers are advised to (1) not only orient learning on teachers and students use to the book alone, (2) 
primary school teachers are expected to improvise the learning by using fulcrum landing which is for fun elementary school age students.

\section{REFERENCES}

[1] H. Rahim, M. Dinia, and H. Rahiem, "The Use of Stories as Moral Education for Young Children," Int. J. Soc. Sci. Humanit., vol. 2, no. 6, pp. 2-6, 2012.

[2] N. S. Al-mansour and R. A. Al-shorman, "The effect of teacher's storytelling aloud on the reading comprehension of Saudi elementary stage students," $J$. King Saud Univ. -Languages Transl., vol. 23, no. 2, pp. 69-76, 2011.

[3] T. D. Johnson and D. R. Louis, Literacy though literature. Australia: Heinemann Porsmouth, 1987.

[4] Ya-Ting, Y. C, and W.-C. I. Wu, "Digital storytelling for enhancing student academic achievement, critical thinking, and learning motivation: a year-long experimental study," Comput. Educ., vol. 59, pp. 339$352,2012$.

[5] K. L. Lium and M. A. Sullivan, "Pragmatics and Aesthetic Reading: From Theory Based Analysis to an Analytic Framework," Education, vol. 3, no. 6, pp. 294-302, 2013.
[6] S. Colville-hall and B. O. Connor, "Using Big Books : A Standards-Based Instructional Approach for Foreign Language Teacher Candidates in a PreK - 12 Program," Foreign Lang. Ann., vol. 39, no. 3, pp. 487-506, 2006.

[7] Desmita, Psikologi perkembangan peserta didik, panduan bagi orang tua dan guru dalam memahami psikologi anak usia sd, smp, dan sma. Bandung: PT Remaja Rosdakarya, 2009.

[8] Triyono, Perkembangan peserta didik. Malang: Fakultas Ilmu Pendidikan Universitas Negeri Malang, 2012.

[9] Rumidjan, Dasar keilmuan dan pembelajaran sastra anak SD. Malang: Fakultas Ilmu Pendidikan Universitas Negeri Malang, 2013.

[10] Sumanto, Pendidikan seni rupa di sekolah dasar. Malang: Fakultas Ilmu Pendidikan Universitas Negeri Malang, 2011.

[11] A. F. Greenhoot, A. M. Beyer, J. Curtis, and J. M. Zosh, "More than pretty pictures? How illustrations affect parent-child story reading and children's story recall," Front. Physchology, vol. 5, no. July, pp. 1-10, 2014. 